\title{
The prayers, tears and joys of Don Cupitt: Non-realist, post-Christian spirituality under scrutiny
}

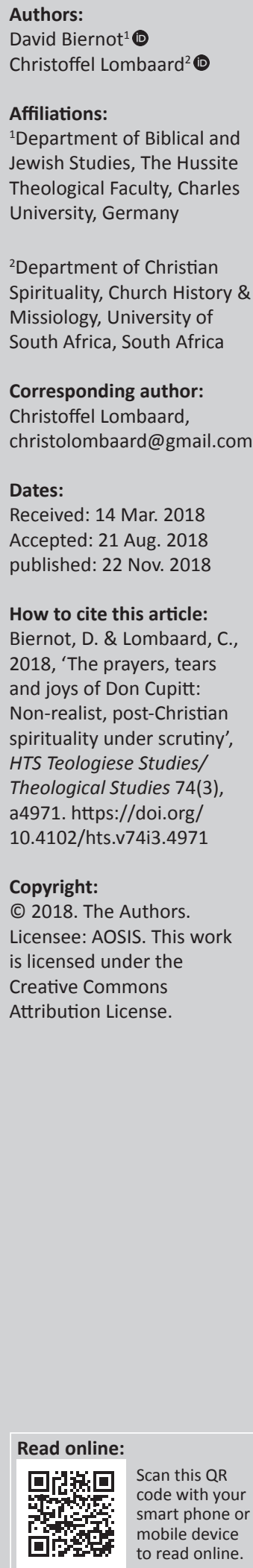

\begin{abstract}
In this contribution, the authors describe the theological contribution of Don Cupitt, initially in stronger relation to Jacques Derrida and also contextualising his insights through the work of some of his predecessors, contemporaries and those who write in his wake; also, in relation to his times and the trends on which he reacts. The latter is also transposed to some currently unfolding theological, ecclesial and societal trends internationally. The main emphases on Cupitt highlighted here may well, different to what initial reactions might be, be of value for certain groups of Christian believers.
\end{abstract}

\section{Derridadaisms ${ }^{1}$}

The authors have conceived of the title of this article as an allusion to John Caputo's monograph The Prayers and Tears of Jacques Derrida: Religion without Religion. This book, penned some 20 years ago, was Caputo's homage to Derrida and to what can be vaguely described as the latter's nonreligious religious sensitivity, rendered as a 'passion for the impossible'. Derrida was Jewish, though without commitment to the Jewish religion. He was an atheist; more precisely: an atheous person, without allowing himself the attraction of negative theology and its refined ways of affirming God's existence through such formulations as 'hyper-existence' or 'existing-by-notexisting' - although there are Derrida readers who have attempted to understand him along such lines (Almond 2000:229-344). Not unlike Monica, the mother of Derrida's late-antiquity countryman Augustine of Hippo, Mrs Georgette Safar Derrida concerned herself with her son's spiritual well-being, impaired in her disquiet by his lack of faith. Yet, as Caputo put it with reference to Derrida's semi-autobiographical Circumfession, 'Jackie' had a religion articulated in secretive speech, in which he talked of God all the time. It was a language of (in the by now famous poetic quote from Derrida 1993):

\author{
inviting calling promising \\ hoping sighing dreaming \\ convoking invoking provoking \\ constituting engendering producing \\ naming assigning demanding \\ prescribing commanding sacrificing. (p. 314)
}

As though alluding to Shemoneh Esreh, the 'Eighteen Benedictions' of the central prayer of Judaism, in the above quote Derrida proposed 18 ways to pray, weep, dream of and open up to the promise of the Unimaginable and to desire the advent of the Impossible. This desiring also presents itself as prophetic aspiration born on the wings of deconstruction, a movement of 'transcendence', pushing against the immanent as the sphere of not only the actual and present but also foreseeable and in effect also representable. No wonder therefore that Derrida has at times been cast as a mystic (cf. however Shakespeare 2004:109-111 on Derrida's change and nuance in this regard). Deconstruction hearkens upon the Irrepresentable, propelled by the expectation and enchanted by the hope and promise of the Impossible. Derrida's religion thus took up characteristics of 'structural messianism', refined however to the 'pure awaiting of what one does not expect yet or any longer' (Caputo 1997:xviii-xx).

Irrespective of how much both authors here treasure Derrida's import for contemporary theology, our current interest lies with another star in the sky of religious thought for almost 40 years now, Don Cupitt. This British philosopher of religion, ordained Anglican priest and former dean of Emmanuel College in Cambridge, not unlike Derrida used to refer to God as 'impossible' - or to 
be more precise: the 'impossible love' (e.g. in Cupitt 2007). Whereas Derrida's sight metaphorically speaking expectantly lingers on into the future, Cupitt has no qualms to posit God as 'the impossible love' in the past and as a fully representable entity. Cupitt's is the dead God of Western metaphysics and of the Christian metanarrative: there seems to be no future for God anymore (Cupitt 2011:19-21).

Cupitt, now aged 83, has undergone an interesting spiritual journey, with both groundbreaking and partial twists, over the past 40 years. Having started as a radical Anglican apologist with an inclination towards negative theology, his entirely new path took off with his Taking Leave of God in 1980, in which he deemed Christianity in its current supra-natural garb to be entirely untenable. Cupitt expected fewer and fewer people would be willing to subscribe to the metaphysical doctrines required by church teachings, while significant numbers of churchgoers would eventually subscribe to a fully demythologised religious humanism (Leaves 2005:14-20). In spite of several further stages and twists, reflecting new incentives coming from philosophy, culture and globalism, the basic gist of Cupitt's religious philosophy has remained the same. If unfamiliar with the basic tenets of Cupitt's thoughts, one may suspect the now obsolete secularisation thesis at work here, which theory failed to materialise in most corners (geographical as much as social) of the Western/ised world (cf. the older vs. the younger Peter Berger as perhaps the example from the Humanities - cf. Berger $2011^{2}$ ), especially since the arrival of so-called post-secularism (Cox 2013:xi-xxxv). ${ }^{3}$

Speaking of the death of God, it may even be argued that the so-called 'Death of God Movement' was one of the shortest lived movements in the history of Christian theology, achieving its peak in the second half of the 1960s, to fade away fast in the 1970s. While Thomas Altitzer understands the death of God in metaphysical terms, informed by Hegel's speculative rendering of Christianity, Paul von Buren focused on the vacuity and impossibility of God language; Kenneth Hamilton underlined the ascent of Bonhoeffer's 'religionless Christianity', with few who like Cox and Gabriel Vahanian adopted this phrase as a cipher for the secularisation of

2.Other examples may be found too: Harvey Cox, for instance, in 2013 entirely withdrew from his original position in the introduction to the 45th edition of his The Secular City: Secularization and Urbanization in Theological Perspective.

3.Would it be fair to single out, if asked to, Jürgen Habermas's 'Secularism's crisis of faith: notes on post-secular society' publication (Habermas 2008:17-29) as marking the influential (though not the initial) starting point in the current interest in post-secularism? post-it nocularism may namely be understood as the currently developing broad, implicit acceptance of religion as a "normal part of life; that is: neither to be privileged (as in pre-modern times) nor to be sideline (as in modern and post-modern times). No evangelical revival, post-secularism is, rather, constituted by the growing tacit acknowledgement that religion is as natural a part of individual and societal life as any other; moreover, that (quoting here from the closing paragraphs of Benson, IT, Lombaard, C \& Otto, E 2018. Faith and Society. Private and Public Religion in Law and Theology. Australian public lecture series: Notre Dame School of Law, Sydney; Australian Catholic University, Brisbane; Pilgrim Theological College, Centre for Research in Religion and Socia Policy, University of Divinity, Melbourne; School of Ministry, Theology and Culture, Tabor College, Adelaide \& Adelaide Law School of the University of Adelaide. Publication forthcoming. HTS Teologiese Studies / Theological Studies 2018): 'To Publication forthcoming, HT Teologiese Studies / Theological Studies 2018): 'To afford prominence within society to any one of these positions on faith/in faith, as had become something of an instinct in democracies to afford atheism, is therefore not a religion-free position, as is always claimed, but is fully a religious stance. Atheism is a confessionalorientation. A state or society or group professing atheism, is taking a religious/confessional stance ... that the ubiquity of religion, the inevitably of faith be recognised for what it is ... Whether acknowledged or not, religious faith permeates everything'. society (McCullough \& Schroeder 2004:xviii-xxvii). For Cupitt, who alongside Lloyd Geering (2014) and others, seems to belong to a 'second generation' of the proponents of the death of God theology, it is rather the failure of the inner workings of theism that leads to the demise of God. In Taking Leave of God, Cupitt exposed the lack of ability on the part of modern theology to defend and stimulate the further development of the idea of objective theism. This criticism is levelled inter alia against shortcomings in the concept of God's governance of the world and the justification of evil within the framework of theism (Cupitt 1980):

This kind of theologians' talk of providence is however by now so attenuated as to be worthless. Why have theologians weakened it so much? Largely to avoid the ugly eudaimonism of the popular idea of providence. People namely tend to talk of providence in connection with fortunate coincidences, lucky escapes and personal success, as if the universe revolves around themselves and God's chief preoccupation would be smoothing their pathway through life. Air-crash survivors for instance thank God for their deliverance, but what about those who had died? A God who schedules some to survive and some to die in a forthcoming air-crash is clearly repugnant. Who can seriously suppose that the world is run in such a way? For a theologian who cannot face such a particularist or close-up idea of providence, providence is only endurable at the most general level. Then however the terminology has to be made so general that the idea of providence becomes emptied: like government by personal rule, however enlightened, will always in the long run be morally intolerable and spiritually oppressive, good government is government by general law. Just so, by implication: if God is good, God must fade out, and if theologians wish still to maintain that there is something like good providence, that will have to be made so general and law-like as practically to disappear. (p. 7)

In his influential Theodiceé, Leibnitz (1710) divides evil into three kinds: moral, natural and metaphysical. It is especially the latter two that have preoccupied modern and postmodern humanity. On suffering and pain, therefore, the question is asked: why has the Creator designed a law-governed world as the arena for so much suffering? Metaphysical evil, in turn, exposes the nakedness of our being as finitude, contingency and death (Cupitt 2012:21-22). Although never referring explicitly to the thesis of the evidential problem of evil as articulated, for example, by the moderate atheist philosopher William Rowe, Cupitt would have probably consented to the latter's syllogistic reasoning (here as summarised from Trakakis 2007):

A. There are instances of evidential suffering which an omnipotent, omniscient being could have prevented without thereby losing some greater good or permitting some evil that would be equally bad or worse.

B. An omniscient, wholly good being would prevent the occurrence of any intense suffering it could, unless it could not do so without thereby losing some greater good or permitting some evil that would be equally bad or worse.

C. Therefore, there does not exist an omnipotent, wholly good being. (pp. 47-75)

The purpose here is to present Cupitt's position as a difficult but still a viable form of spirituality for a segment of practicing 
Protestant Christianity, to be specified below. While the first author here numbers himself among those who deeply appreciate Cupitt's non-realist vision of Christianity, the attitude of the second author tends more towards the postsecular. ${ }^{4}$ However, both of us agree with Cupitt's conviction that our generation may be living in what he, inspired by Karen Armstrong, tentatively called a 'Second Axial Age' (Cupitt 2001a:7-8). The first 'Axial Age', a phrase earlier coined by Karl Jaspers, spanned from 800 to 200 years $\mathrm{BCE}$, with this period laying the ground for the next two and a half millennia for what were to become the leading standard conceptions of the world, the self, knowledge, action and the way to happiness. During this long epoch, Christianity was in Plato's debt, as it extensively relied on Platonism in its various forms and modifications and in its syntheses with Aristotelianism. It was above all Plato's ontology which created a massive gap between our world, phenomenally speaking, and the world of intelligible eternal structures 'above', with an anthropology that separates soul (mind) and body, with as a corollary the understanding of human life as a temporary journey 'up' to an eternal abode, after death. However, in the past three centuries Western/ised civilisations have been gradually ushered into a new age - not in its usual current sense of a new religious movement, but in the sense of an age of rationalism since the Enlightenment, in which its adherents have become profoundly post-metaphysical, de-centred and 'de-logicised', presenting the world more as an unpredictable fluidity than a firmly given order (Cupitt 2001a:8-14). The results of the ontological and epistemological debates over the past 50 years have provided ample testimony for us having lost a consensus on what the notions of Reality and Truth ought to signify, finding ourselves in the heat of the battle of various, mostly antagonistic models (Lopez \& Potter 2005:1-19; cf. Collier 1994:1-30; Schreiber 2013 \& Schreiber 2012:1-8 and the literature cited there).

The second aim of this article is to present Cupitt's spiritualityafter-God as a viable option in particular for Protestants who are not willing to turn their backs on the legacy of the Enlightenment, which aversion had become symptomatic of much of fundamentalist, charismatic, Pentecostal and related expressions of Christianity. The present contribution is intended for some of those who appreciate and hold precious the opportunities offered by the secularised spaces of pluralistic democratic societies, who care about the levels of general happiness ('well-being' and 'flourishing' are current terms in this regard), social equality, ecological awareness and the rights of minorities such as the LGBTI community, and who refuse to compromise their positive attitude to the scientific communities and their discourses. Critical engagement and spirituality are thus not held to be at odds with one another (cf. De Villiers 2006:99-121).

In his book Religion Under Attack: Getting Theology Right, Nigel Leaves describes the phenomenon of post-secularism not so much as the resurgence of interest in religious matters,

4.See Schreiber 2012:1-8 read with Schreiber 2017:1-9. but rather as the drifting apart of neo-conservative religious communities on the one hand, and secular, science-oriented segments of the public, on the other (Leaves 2011:967-1267). It seems that both communities have lost the ability to see eye to eye, becoming more and more irritable and prone to flex their muscles at each other. We can discern a growing number of people who declare openly that the God hypothesis is redundant and that humankind can develop effective ethics and create a common humanity without taking recourse to religion. This is a clear legacy of rationalism and a sentiment typical of the modernist mind. In the context of rising absolute numbers and proportions of religiosity, taken globally, atheists have increasingly become organised and confrontational to combat what they see as a deliberate attack by fundamentalist or neo-conservative religious groups on the liberal, open society in general, and on science in particular (Leaves 2011:697). At the forefront of this surge stand personalities like Richard Dawkins, whom Leaves has labelled, with a jab of sarcasm, as a man with 'evangelical fervor' for his zeal to convert the masses to atheism (Leaves 2011:1624).

Leaves paints a grim picture of a disrupted and particularised society consisting of 'ghettoised' segments, each pursuing its own ideological agenda. Some $85 \%$ of US National Academy of Science members do not believe in a personal God (Leaves 2011:1196). Carolyn Porco, the NASA scientist and head of the imaging team for the Cassini space probe to Saturn, had for instance said that the beauty of space is much more satisfying than anything religion can offer (Johnson 2006). In the same breath, she countered the promise of immortality with the claim that all the atoms of our bodies will ultimately be blown into space at the disintegration to life, forever, as mass and energy. This, in her opinion, 'is what our children must be taught and not myths about angels or seeing grandma in heaven. If anything has something to replace God, I think scientists do' (Leaves 2011:1202). When we imagine these scientific communities existing alongside neo-conservative Christians battling evolutionism and promoting creationism, a rupture marking many Western/ised societies becomes clear, to say nothing of the political implications of such divisions. (The connection between neo-conservative circles and the current administration in the White House has been detailed in the recent bestseller Fire and Fury: Inside the Trump White House by Michael Wolff [2018]).

The authors of this article began to pay closer attention to the highly critical and intellectual content of Cupitt's religious philosophy as a result of our own long-standing dissatisfaction with the stream of Protestant spirituality that has carved out a safe niche for itself in the area bordering on psychology, psychotherapy and related disciplines, contributing in this way to the 'therapeutisation' and erosion of intellectualism within Protestantism (Biernot \& Lombaard 2017:1-12). Our intention is not to be prejudiced, yet our conviction is that much of this development is to be blamed on the objectives pursued by broad streams within the churches that have 
transformed the message of the Gospels into a farce, namely through an infantilisation and a strong anthropomorphisation of God. This decline has been convincingly described by Todd Brenneman in his 2014 Homespun Gospel: The Triumph in Contemporary American Evangelicalism (cf. in South African context, the contribution of Cilliers 1996). Evangelicals have forfeited their rich intellectual heritage.

The appeal to intellect, which according to Brenneman was still in the first half of the 20th century present in AngloSaxon conservative Protestantism, as it felt itself committed to the understanding of biblical revelation informed by a Baconian approach to nature that believed the natural world was best understood by searching for facts and inductively determining general truths, has been overtaken by sheer sentimentality (Brenneman 2014:52).

In most evangelical bestsellers written in the past 20 years, readers are encouraged to conjure up a picture of God as an extremely dedicated and loving father lavishing attention on them. For example, in In the Grip of Grace by Max Lucado (1996), one stumbles upon strong emotional exhortations portraying God as the one who is available to us $24 \mathrm{~h}$ a day, clearing the track for our daily competitions, cheering us up and applauding us, giving thumbs-ups, booing our competitors, carrying us when we are out of steam. If God were a physical being living in a physical house, that house would be stuffed with mementos of you; if God had a car, your name would be on the bumper (Brenneman 2014:29). It is clear that fatherhood serves here not as a theological concept in the first place but as a strongly emotional and sentimental trope. This kind of evangelicalism provides a sort of spirituality that is carefully tailored to the most pronounced individualism. It is embedded in the context of a highly competitive neoliberal market society, also with a marketplace of religious goods and services. In this conception of the world, the bloodstream of each individual has continually to be flooded with high doses of dopamine, boosting their positive feelings, suppressing depressive moods and stimulating the self-esteem and confidence necessary for achieving success in the ubiquitous competitive games.

This sort of therapeutic spirituality has taken hold of large swaths of Protestant culture in the United States and, in its cultural wake, elsewhere in the world. Its seemingly cheerful, self-confident and healthy face cannot however belie the indicators of an appalling truth about a religion that has already seen its heyday and is now only a shadow of its previous self, a testimony to a long dead God. Noteworthy is also the growing popularity of supra-naturalism among evangelicals, such as the belief in the ubiquitous presence of evil spiritual beings with their malevolent influence on everyday life, in the form of demonic possessions with the necessity constantly to exorcise them. This leads to the further dissemination of a strongly dualistic conception of the world (cf. the Platonic views indicated above), especially among many Pentecostal evangelicals (McCloud 2015).
The above forms part of the context, albeit an important part, in which the work of Cupitt comes into its own, namely as a critical, yet not unemotive, alternative.

\section{God as an impossible love}

God is dead. This is the basic proposition echoing throughout Cupitt's works, from his already mentioned Taking Leave of God up to Creative Faith: Religion as Worldmaking, published in 2016. Much in consonance with the history of religious ideas, Cupitt claims that the idea of God as Ens Realissimus, the most real Being, the self-existent und unifying Ground of all reality, is a congealment of Greek metaphysics and biblical theism. This theology probably saw the light of day already in the philosophy of Philo of Alexandria, to become fully developed in the theology of Augustine around $400 \mathrm{CE},{ }^{5}$ which had held full sway until more or less the 1700s. However, after Berkeley and the Leibnizians, shortly after 1730, Western thought was confronted with a new situation in which God as a working hypothesis became ever less convincing. God had started to fade away fast, so to speak, as new paradigms in philosophy, science and the order of society made their way to the surface (Cupitt 2012:62-63). Much of the following two centuries God spent in the Intensive Care Unit, treated by a host of neoorthodox theologians and assisted by philosophers still loyal to objective theism.

Cupitt draws on multiple sources while articulating his views regarding this matter. Certainly, Friedrich Nietzsche is not missing among them, but an attentive reader will also notice the impact of Hegel's speculative interpretation of Good Friday on Cupitt's understanding of God's demise. Hegel had namely sought to take up the atheistic tendencies fermenting in the Enlightenment and worked through them positively, giving the idea of the death of God special significance (Jüngel 1983:63-99). However, it should be noted that the motive of the death of God predates Hegel and is, for example, traceable in the mysticism of Meister Eckhart, who for instance speaks in one of his sermons as follows: 'God died so that I might die to all the world and to all created things' (Walshe 2009:126). For Hegel, in the talk of the death of God is expressed the situation of absolutised finitude, set against abstract infinitude as empty negativity. The death of the Christ on the cross conveys the idea of the self-negation of God, who refuses to stay 'in and for himself' and does not desire to forsake the world in its finitude. He gives himself up to destruction and endures finitude up to the harshness of death as the end of the finite. The historical Good Friday illustrates this self-negation and absolute dispersion and dissolution of divine life in the immanence. In certain passages, Cupitt offers quite LeftHegelian-like musings over God passing entirely into the sphere of immanence, stimulating a kind of world-immersed mysticism and secular humanism (Cupitt 2015):

Now note: In the New Testament, and in Christianity generally, God never appears in his most concentrated and terrifying form.

5.We should not disregard the significant contribution to the final stages of the crystallisation of this idea made by medieval Islamic and Jewish religious philosophy, crystallisation of this idea made by medieval Islamic and Jewish religious philosophy,
represented by such outstanding minds as Avicenna, Averroes, Maimonides and represented by such outst
Gersonides (Seeskin 2000). 
Occasionally he appears in the form of a human voice in the sky, but otherwise he typically appears in the human form of Jesus Christ the King - for example, in Revelation, in much of Byzantine art and in Jan van Eyck's Ghent altarpiece. In more veiled forms God may be 'sensed' at the symbolic focus of the church, hovering just above the altar or the icon-screen, or perhaps embodied in the human person (the Holy Father) positioned at the summit of the organized, visible and patriarchal church-institution. Then God is further dispersed, first into mankind at large, and then into the sublime of Nature. At last, in the Tenebrae ritual after the death of Jesus on Good Friday, God is finally dispersed into the darkness and objectivity of his own death. A rather similar progressive dispersal of God into humanity, into nature, and finally into his own death takes place in other faith traditions too. Certainly, Christian iconography as it develops consistently shows the tradition of faith developing and the triumph of an approximately Wordsworthian mysticism combined with humanitarian ethics. (pp. 338-343)

It is clear that Cupitt's reflection of the death of God lacks the metaphysical dimension present in Hegel's interpretation, or even in Dietrich Bonhoeffer's, according to which God has withdrawn from this world (Jüngel 1983:101), or finally in Altizer's (2006). For Cupitt, the death of God is intrinsically a cultural event. It is an event that took place in the history of the Absolute Spirit (à la Hegel, thus), interpreted as the progress of human language practices. Inspired by Ludwig Wittgenstein's philosophy of ordinary language, Cupitt has become a very diligent and attentive student of ordinary, colloquial language situations and its turns of phrase, arriving at the conclusion that the word 'God' has a propensity to be dropped from the colloquial language practices of the British public and elsewhere in the Englishspeaking world. He collected hundreds of new phrases, noting the overwhelming reference to the word 'life' as the replacement for God, and as a new religious object (Cupitt 2012:102-112; Leaves 2004:91-100). In our colloquial language practices the 'supra-natural' has died out and has been dispersed into the ordinariness of our lives. We often take recourse to such phrases like 'wrestling with life', 'loving life' or 'having faith in life', which have over time established themselves as standardised expressions through which we have consciously or half-consciously transformed God into the encompassing notion of 'life'.

This dynamic could be read in different ways. One could use the by now classic understanding of Derrida (1976, e.g.) as signs referring to signs referring to more signs, in an ever-continuing chain of referencing that lies beyond our grasp - implying, perhaps, and depending on one's tradition of interpretation, a nirvana-like Nothingness at the end of it, or an all-encompassing Absolute over all of this, or an incarnate Word that had been pre-existent but was now immanently embodied. One could, not unrelated to this, employ the language of Semiotics, reading signs as significant. One could apply the fruitful concept from Edward Bailey of implicit religion (cf. e.g. Bailey 1997): seeing oft-unintentional referentiality to the divine in the everyday. Herein, therefore, lie also echoes of (quoting here from Lombaard 2016:264-265):
Karl Rahner's understanding of 'anonymous Christianity' in his Theological Investigations, volumes 6, 10, 12, 14 and16 (conveniently collected and discussed in brief by Sau 2001:23-39), on the salvific extention of Christ's significance beyond Christian borders; the mystic insight on the 'one and many' or the 'whole and part' (cf. Krüger 2006:30-31), in which the interrelationships of all that is entangle themselves essentially; and the concept from Sociology of 'spiritual capital'. (from Bourdieu 1986:241-258; cf. O'Sullivan \& Flanagan 2012)

To return to our example from Cupitt: 'life' has thus grown under the hands of several past generations into something bearing personality and disposition - not unlike God. Other strong linguistic candidates presenting themselves for semireligious usage are 'chance', 'happenstance' or '(mis)fortune'. To this may well be added popularly used expressions such as 'the universe' or 'the Universe' which - not unlike the fates in Greek mythology - steers happenstance, a clear allusion to divine providence; and also 'what goes around, comes around', which expresses a kind of karmic conviction that justice will after all be found in life, which on its part alludes to some form of ordained scales of justice that remain in cosmic or universal balance.

Though such expressions understand themselves as modern, which means coming after a Christian age, they are in fact most directly pre-modern, being mythical in nature and cyclical in understanding of time (as seasons, more than seconds, minutes and hours). In that earlier age of an objective God, everything was thought to have a higher purpose; nothing played out in an accidental manner. In this way, illness, especially grave disease, could be interpreted as 'God's visitation' for the sake of trial or the amending of the afflicted person's sins. A misfortune was assigned a moral meaning. From the Upper Palaeolithic era until present times, local or traditional religious systems provided the suffering person with a narrative moral explanation on suffering, and with advice regarding the remedy. However, as pointed out by Cupitt, these cultural patterns had begun to change since the 1960s. Given the remaining non-modern orientations that nevertheless understand themselves as being fully progressive, perhaps a 'some of' should be appended to 'these cultural patterns had begun to change'. While since the Enlightenment conservatively minded people were still likely to ascribe their own or someone else's personal tragedy to a higher purpose, others weaned themselves of this practice, asserting thereby their liberty from the theological and moral implications attributed to misfortune. Cupitt relates in this respect a story of his friend, a Christian minister, who wrote to him after his beloved wife's premature death from cancer that it was for him a relief to think of her illness and death not as supra-natural trial but as mere statistical misfortune - 'Life!' (Cupitt 1998:39-46).

The death of God theology of Cupitt is undoubtedly bound up also with his ontological and epistemological stance: nonrealism. This is a position typical of post-modernism, with the 'reality' of the divine which fits with some cogency into 
the postmodern construction of reality through communities that share a language game. The latter gives deep and full meaning to those included in the game, which commitment can however in analyses be understood as a shared frame which requires no 'real' outer referentiality. In his own words (Cupitt 2011):

Non-realism is a term widely used for the philosophy of God that I first set out in Taking Leave of God (1980). In that book I did indeed say that we need to break with our traditional realism (the view that theological statements purport to stand for objective theological facts about God etc., facts which do not depend on our faith in him - especially in the great monotheistic traditions - is objectively oriented and makes objective claims). Influenced by Kant's doctrine of God, I set out an alternative view of God as a guiding spiritual ideal and an necessary myth to live by. Trying to establish the autonomy of religion, I made God internal to religion, thus rejecting the old view which saw human religiousness as dependent upon, and as hoping to be vindicated by, an objectively existing God. In The World to Come (1982) I went a step further and defended 'theological grammar', a view which sees religious beliefs as 'regulative' or life guiding. For example, it maintains that to speak of God as one's Father is not to describe God as being anything like one's biological parent, but to say that we should live confidently and be diligent, if a fatherly eye watched over us. On this view, religious belief is very highly practical: it doesn't tell us facts about Cosmos: it just shows us how we should live. (pp. 81-82)

Cupitt's position can probably be best understood in comparison with the non-realism of the American neopragmatist philosopher Richard Rorty - to whom Cupitt makes occasional reference. Rorty made cause for the repudiation of the idea that mind or matter, self or world, possess an intrinsic nature that can be expressed or represented. In his opinion, a distinction must be made between the propositions that the world is out there and that the truth is out there. The first proposition intends to say that:

most things in space and time are the effects of causes which do not include human mental states. To say that truth is not out there is simply to say that where there are no sentences there is no truth, that sentences are elements of human languages and that human languages are human creation. (Rorty 1989:5)

It is hence our language that would summon and order the world and commits us to time, secondariness and ambivalence, stripping us of the chance for unmediated contact with reality. This is the point of departure for Rorty, forcing through a strong theological proposition which seems to reverberate with Cupitt's version of non-realism. According to Rorty, the proposition that truth as well as world are out there is a legacy of the age in which the world was seen as a creation of God, with God having an own language - that of the Logos. Presupposing the existence of such a non-human language makes us posit a universal, (supra)natural Script that splits the world into self-subsistent facts which the human mind can comprehend and represent (Rorty 1989:4-6).

Cum grano salis, both of them, Rorty and Cupitt, take us away from Philo of Alexandria, the first thinker deliberately to found the edifice of his thought on a robust Logos theology, heavily relying on Plato's legacy. If there are no humanly created sentences, and no non-human language, there is also no Speaker to use it - no objectively existing God. It is in this context that Cupitt could pronounce both God and realism dead (Cupitt 1998:26-38).

With no divinely instituted language, this world amounts solely to the changing paradigms of human communication, with no chance really to distinguish between these paradigms. Ontology has thus been replaced by semiosis. The world of our experience hence consists of tingles in our sensory nerves that are formed into sensory qualia by language. It is the very same language that creates a continuous Umwelt around us. In Cupitt's words (1995):

The philosophical doctrine I am propounding is very simple. It is that we do best to picture the world as a beginningless, endless and outsideless stream of language-formed events that continually pours forth and passes away. (p. 23)

Rorty (1998:123) would say that the stimuli input as the process of undergoing physical changes prompted by the environment is rather 'thin' compared to the extensive output, resulting in a 'thick' web of conversational practices.

In both cases, the language of language predominates: the master narrative of post-modernism is the metaphor of words, sentences and statements. The early insistence of New Criticism in literary studies that fervently disallowed external referentiality would necessarily lead away from ontology to epistemology only. Diesseits precludes Jenseits, in this kind of understanding of the constitution of and formulation on life, reality and all that is.

In the same breath, however, Cupitt vigorously denies being an atheist. Stopping to affirm the existence of the objective God, such a view can be defined only as being 'objectively atheous' (Cupitt 1980):

For over the years I have tried to combine the belief in God with spiritual freedom by pressing the themes of the negative theology and the divine transcendence even harder. Eventually I was saying that God does not determine and cannot be thought as determining the spiritual life from outside, for God is altogether unspecifiable. God had to become objectively thinner and thinner in order to allow subjective religiousness to expand. It is only one step further to the objectively atheous position here propounded. (p. 14)

Rejecting a realist God does not of necessity entail the rejection of God as such, though. Leaves (2005:73) portrays Cupitt as a religious person sui generis, praying and attending the Eucharist at Emmanuel College Chapel on Sundays as a kind of 'Kingdom meal', and as one who never resigned his priestly orders. The involvement in Christian religious practice still makes sense for Cupitt, even though God is 'only' a mythical embodiment of all one is concerned with in the spiritual life. In his 2007 book Impossible Loves, Cupitt sheds light on his somewhat Derrida-like piety. His relation to God is a relation of 'impossible love'. God is one of the 
objects most of us strongly yearn for which cannot be attained. Cupitt includes among these kinds of loves above all our emotional attachments to our dead parents. Although they are no longer alive, we may still catch ourselves thinking of or talking to them. They have, so to speak, taken hold of our imagination, and in their non-existence they appear to us in some respects more real than they had perhaps been during their lifetime. We imagine them to be in some place and hope to join them one day (Cupitt 2007:9-14).

Cupitt has analysed the turns of British spirituality since the 19th century to find out how much it has been suffused with nostalgia for God. Still, in their loss of belief in God, a lot of people felt the urge to continue to pray and display positive emotions on God and to carry on religious practice. Even today, for some at least, theological propositions would seem to be of immense importance. Cupitt (2007:21-24) interprets this phenomenon as a paradox in which the death of God, rather than leading to a relinquishment of interest in religious matters altogether, has stimulated some people to pay intensive attention to these matters, albeit with an aching nostalgia for God. This group has faced difficulties in describing and sharing their religious stance with both churched and unchurched publics, with some of them turning to such neologisms as 'Anglo-agnostics' or 'Angloatheists' (Cupitt 2007):

The Church is a cosmic society: an idea so compelling that people do not give it up lightly even though they freely admit that they are no longer anything like orthodox believers. The English writer Rose Macaulay coined the term 'Angloagnostic' to describe her own position - a position shared, I would say, by the minor poet John Betjeman - and several prominent 'Anglo-atheists' inhabit today`s Cambridge. They go to church and to their College Chapels, as the astronomer Sir Martin Rees puts it, 'for historical and cultural reasons'. Nobody expresses surprise. (p. 30)

Cupitt in this manner catches red-handed even the staunchest atheists such as Richard Dawkins, who despite his ambition to exorcise God from the minds of the masses, is still strongly dependent in his argumentation on traditional theistic conceptions in Western thought: the universal language of the world, reality, objective truth (Cupitt 2007:29). Despite living in a post-Christian culture, a relation to God is still upheld, or at least some semblance of it. For instance, the $\mathrm{BBC}$ has recently begun to air a comprehensive documentary series on the natural history of the world's oceans called 'The Blue Planet 2', narrated by Sir David Attenborough, an agnostic. His narration is obviously based on pieces of consensual knowledge supplied by various branches of the natural sciences. Yet, an attentive viewer can discern religious undertones sneaking into the soundtrack by Hans Zimmer (the composer of the musical background score). The views of magnificent watery sceneries are from time to time musically speckled with 'Hallelujahs' performed by an orchestra and a choir, inadvertently reminding one of Old Testament psalms praising God as the designer and the creator of the world. These are hints of a different narrative supplementing a purely naturalist, scientific one. This is a good example of persisting religiosity, perhaps one labelled by the Italian sociologist of religion Roberto Cipriani a 'diffused secular religiosity' (Cipriani 2017:65-81).

Some find Cupitt's 'residual' piety embarrassing, if not bizarre. One of the most recent such authors, Robert Michener, has ridiculed it as 'theological necrophilia' (Michener 2007:141-155). Others, such as the post-liberal theologian Robert Cathey, are more forthcoming in their understanding.

Cupitt's criticism of metaphysical realism cannot easily be dismissed. His work represents 'a diagnosis of the intellectual and cultural ills western ecumenical Christianity is battling with' (Cathey 2009:182-185). Cupitt's voice speaks for those who no longer find the concept of a God of metaphysical monotheism at the centre of their concerns. In spite of this privation, they still regard certain religious practices, symbols or places transformative and life-giving, regardless of whether such instances would for them point to the transcendent signified called God. Cupitt may be speaking for some churchgoers not willing to share openly their views. They may be professionals in education, the arts and science, therapy, and even church ministry; ${ }^{6}$ all those who have embraced Feuerbach's and Freud's more recent reductive understanding of religion: 'human religious behavior is a projection-game of the imagination in which the referents of our images of God are our idealized, best sense of self and society' (Cathey 2009:184).

\section{Solar Cupitt}

The death of God is not only a source of grieving or religious nostalgia for Cupitt. Rather, the loss of the God of metaphysical realism and the hope for immortality liberates us to the possibility of experiencing the fullness of life, embodied in our individuality as well as in relationships, hic et nunc; in its ordinariness, amid tragic or comic life situations (Cupitt 1995:74-78; 2012:52-60). In the speculative Good Friday, God's transcendence has been nullified and entirely absorbed by immanence. Cupitt (2011:3) therefore coins the expression 'All this is all there is': the ordinary lifeworld, given us in the language we daily use. This lifeworld is 'outsideless'; that is: it is and will be the only world we will ever have.

Cupitt opts for 'ecstatic immanence', accepting the transience of everything around us (thus echoing in various ways the Old Testament book of Ecclesiastes, Friedrich Nietzsche and 20th century French existentialist philosophy). In this mode of existence, we cease to be separate, self-conscious

6.One of the most vocal non-realist ministers these days is Gretta Vosper, an ordained minister of the United Church of Canada. Her removal from the ministry as a result of her 'atheous' views has not been resolved by the church's General Council yet. See her book With or Without God: Why the Way We Live Is More Important than What We Believe published in 2012. On the Dutch scene, a similar matter has been resolved with Klaas Hendrikse, who pastors in the Protestant Church: see Hendrikse resolved with Klaas Hendrikse, who pastors in the Protestant Church: see Hendrikse $(2007,2011)$. The same goes for theologians in academia too, making their atheous views public (with on the South African scene Unisa Old Testament scholar Sakkie Spangenberg being perhaps the example), at times endangering their careers in the process (with, again on the South African scene, University of Pretoria Practical Theologian Julian Müller being perhaps the best example). Leaves (2004:27) points out that Cupitt's publication of Taking Leave of God coincided with his gaining the safety of a tenured position in Cambridge. 
individuals, standing aside from life - which used to be the paradigmatic behaviour commended as the most suitable for the 'citizens of heaven' (Philippians 3:20) by Christian culture for centuries, which on its part fit rather snugly with the presuppositions of modernity around objectivity. Instead of that, we would, following Cupitt, allow ourselves to be catapulted out of our inwardness and now be put adrift in the flux of language-formed events (another postmodern moment, with language as key explanatory category). One is encouraged to be overcome by the awe of transience, savouring it in a religious experience called Lebensgefühl by Cupitt, which borders on a kind of 'empirical aestheticism' which would include certain qualities:

- So far as religion is concerned, the end of belief in any personal life after death seems to have the effect of propelling us into life now, in the present moment. It immerses us into a form of extrovertive visual mysticism: we are lost in love for the world, for the iridescent flux of phenomena and for all of life (Cupitt 2015:1310).

- Ecstatic immanence is undoubtedly not an introvertive kind of spirituality, which kind prevailed in the Church for at least one and half millennium, implanted by Platonism. Introvertive piety turns inward, away from the senses, away from human company and all merely human images of divine (Cupitt 2011:33). Cupitt adopted its opposite, 'extrovertive expressivism', marked by a pouring out into the transience of the world and forgetting one's own self (the latter itself a Christian or Western mystic kind of living). In this respect, Cupitt is no stranger to ideas stemming from the religious lore of Buddhism which, in Cupitt's opinion, through its distrust of human subjectivity balances well with the personalism now ingrained in the Christian tradition (Cupitt 2012:31-36).

In our times, this kind of spirituality stands in stark contradiction to the personalism of evangelical piety, in which the most important thing in life is to gain personal peace with God and the assurance of final salvation. This can be achieved only through an intense person-to-person commitment in the relationship with God. This, as we have seen earlier, can be perverted into excessive sentimentality, bordering on infantilism and stands fully in the wake of Enlightenment individualism. Cupitt quite often refers to the extrovertive or 'expressive' spirituality as a 'solar living' or 'solarity', drawing on the symbol of the Sun as a symbol of pure affirmation and continual self-outpouring. In this, he is not new, though the antiquity of these roots also within Judeo-Christian heritage is seldom realised (cf. Arneth 2000). Cupitt's expressiveness possesses strong ethical underpinnings, finding anchor in the understanding of Jesus as a moral teacher rather than as a supra-natural saviour (Cupitt 2011:57-59). In this, Cuppit's image of Jesus comes very close to that promoted by Crossan (1993) in his groundbreaking The Historical Jesus: The Life of a Mediterranean Jewish Peasant (a not surprising resemblance as Cupitt, too, has joined the ranks of the Jesus Seminar). Cupitt hence indicates some passages from the Gospels believed to be the oldest layers of tradition, which would come closest to authentic Jesus sayings, for instance, some parts of the Sermon on the Mount, as being explicitly 'solar'. (The parallel to some strands of feminist Bible scholarship identifying in the sophia concept a kind of ideologically purer Gospel, for example, in the work of Schüssler Fiorenza 1994, is noteworthy.) In other Bible passages, Cupitt discerns another voice, more otherworldly, a voice of the churchy 'Catholic Jesus' (Cupitt 2012:54-57). For Cupitt, the historical Jesus seems never to have encouraged people to retire into their inwardness, but rather to come out like the sun (cf. Mt 5: 14-16). Someone's religious life is supposed to be wholly this-worldly, pouring itself into sacrificial love and excessive generosity, not succumbing to resentment. This message is the only part of the Gospels which can effectively operate even in the post-Christian age, Cupitt (2015:216-317) maintains, and which these days finds its expression in secularised Western humanitarian ethics.

\section{Don Cupitt also for churchgoers?}

Cupitt is a well-known religious thinker, with his writings as well as his public speaking activities having played an important role in the establishment and growth of the Sea of Faith networks throughout the countries of the former British Commonwealth. These networks provide and outside-thechurch setting for discussing religious and public matters without ecclesiastic censure. Today, this movement numbers approximately 2000 people coming from different religious and nonreligious backgrounds (Leaves 2005:117-118).

What is, however, the possibility of integrating the highlighted features of Cupitt's spirituality into more general ecclesiastic practice? In simple terms: Can a 'regular' churchgoer be non-realist?

Some of Cupitt's adversaries, such as Brian Hebblethwaite, rule out such an option. Hebblethwaite (1988:15-16) brings to attention the difference between metaphysical (realist) and expressivist (non-realist) views of Christianity. The love acts of Theresa of Calcutta for the poor and sick were namely different from what a secular relief worker does. There is moreover a substantial difference between those who depend on a Higher Being to support them and those who rely on God as a leading idea only. When it comes to practical aspects such as public and private worship, religion must have an objectively existing referent, in order for its adherents to experience that relationship-in-faith as meaningful. Religious language tumbles in, upon itself, lacking such an external referent (Leaves 2005:91-92) - an essentially non-postmodern position, as it breaks away from language as all-determinative explanatory metaphor.

On the other hand, though, some view the ecclesiastic setting as the least suitable environment for the realisation of the ideas of religious non-realism. Above all, churches cordon themselves off into 'intellect-free zones', unable to engage critically with difficult questions of faith - and its seems that it is the marginalised who have to bear the brunt of this state of affairs (Leaves 2005:96-97). In this respect, it would not be 
out of place to mention non-ecclesiastic gatherings called 'Sunday Assemblies', built on church models, though, which have recently received a fair amount of attention as they foster critical thinking, providing a hub for a church-like communal sharing and mutual solidarity in today's strongly individualist, consumption-oriented and at times socially dysfunctional societies in Europe, the United States and elsewhere (Piggot 2013).

Cupitt's own position on this issue seems however to have been wavering too, as he found himself in a dilemma with no clear solution, as shown in the below quote. He tries to extricate himself from this predicament by pointing to the unique historical period we live in, marked by a believingand-non-believing dichotomy in which religion resembles a sort of art (Cupitt 2000):

The lesson to be learnt from artists ... is that in post-modernity we are all of us ... in an ironized, both-believing-and-unbelieving relation to our own religious tradition. Artists explore and play with the many different nuances of irony now found amongst us, and the fact that they find a public - often, a very large public shows that we are all of us in varying ways ironized non-realists nowadays. We at-least-half know it is only myth, but many of us remain very attached to it all nonetheless.

Cupitt's analysis of the 'believing-and-non-believing' context of our generation seems to square well with John McClure's (2007:4) characterisation of the place of religion in postsecular literature, for which he coined the term 'partial belief':

Yet, certain features are constant across the field of postsecular texts. The partial conversions of postsecular fiction do not deliver those who experience them from worldliness into well-ordered systems of religious belief. Instead, they tend to strand those who experience them in the ideologically mixed and confusing middle zones of the conventional conversion narrative, zones through which the conventional protagonist passes with all possible haste, on his way to a domain of secure religious dwelling.

And yet the postsecular characters deposited in these zones do not seem particularly uncomfortable there nor particularly impatient to move on to some more fully elaborated form of belief and practice. In a similar manner, the break with secular versions of the real does not lead in postsecular narrative to the triumphant reappearance of a well-mapped, familiar, religious cosmos, as it often does in conventional narratives of conversion. Gods appear, but not God. Other realms become visible but either partially and fleetingly or in bizarre superabundance. Miracles and visitations suggest that the laws of nature may be contingent but without providing any clearly coded alternatives.

Realism and non-realism do not have to be viewed as acrossthe-board responses to all the objects we could conceivably refer to. In our ordinary, everyday negotiating of a way through the world, there are neither pan-realists nor omninon-realists. For instance: imagine attending services in a mainstream middle-class Protestant church, to carry out a poll after worship on which objects the congregants believed to be real. When asked about logical truths, most of the respondents would probably pose themselves as non-realists. Inquired about the objective reality of electrons or gravity, most of them will side with the realists. Questioned about the objective reality of angels and demons, the respondents' answers will with all probability vary. Finally, coming to the question of the objective reality of God, we can assume that some of the congregants might be astonished by their own answers conceding that they more than once in their lives contemplated God as objectively non-existent and that they could live with that proposition. In a postmodern setting, there are undoubtedly ordinary churchgoers as well as ministers entertaining 'atheous' thoughts while being overtly dedicated to their personal involvement in worship and other activities of their religious communities. The logical clarity, or a kind of streamlined single-mindedness, habitually expected of both religious and nonreligious people, often does not materialise. The complexity of the matters at hand and of their relationship to the matters at heart often break down, or perhaps break through, simple consistencies.

Stephen Mitchell (1997) and others see the church membership of non-realist Christians as feasible. For both realists and nonrealists, the re-enacting of the rituals of Church in everyday life, and especially in difficult situations like illness, unemployment, a loss of meaning of life or in bereavement, may play a sustaining role and provide empowerment for working one's way through these difficult moments. Such rites, as, for example, the Eucharist, possess a spiritual value of their own, open to a plethora of interpretations. Room is allowed for this between the Roman-Catholic Church's safeguarding of its 'realist', supra-natural understanding which insists on the 'real' presence of Christ in the Eucharistic elements, along a continuum to some Protestant churches' subscription to a wholly symbolic, 'non-realist' meaning of the element.

Cupitt's religious philosophy is well known in Englishspeaking countries; among this group counts South Africa as well. The same cannot be said of the countries of for instance Central Europe. So far, only one of Cupitt's numerous books has been translated into German (Cupitt 2001b), and his name has until recently been almost entirely unknown on the theological scene of the Czech Republic. This is rather deplorable, given that most of the countries of Central Europe have their own stake in the history of atheism and even in the development of atheous religiosity. Cupitt's thoughts would undoubtedly strike a chord among many religious thinkers in this part of Europe too, as the attempts to articulate the tenets of 'atheous religiosity' have undoubtedly been present at the local scene at least from the 1960s (Vogel 2014).

In practice, there seem to exist more fully atheous societies in Europe, as, for example, in Denmark. According to American sociologist Phil Zuckerman, the majority of Danes have relinquished most of their religious beliefs, as they are able to find meaning of life without supernatural sanction. However, many of them feel attached to the National Lutheran Church of Denmark, paying the church tax, availing themselves of the Church's rites of baptism, confirmation, wedding and burial. Some even continue to attend services on a regular basis. In practice, all of them live in accordance with a 
non-supranatural, non-creedal humanism informed by Protestant legacy (Zuckerman 2008:17-35). In a sense, many Danes might fit into the category of theologically non-realist Christians. Whereas neo-conservative Christians quite often argue that a society without religion (to be more specific, without a realist version of religion) is doomed, exposed as it would be to moral decay, corruption, anarchy and hedonism, Denmark however scores well on indicators of general happiness, social security, high life-expectancy, gender equality, with concomitantly low levels of crime, racial hate and political corruption. According to the Economist's Quality of Life Index (Zuckerman 2008:29), Denmark therefore ranked in the 2000s among the best places in the world to live. Could this perhaps in some manner be an indication that an 'atheous', non-realist version of Christianity could be better equipped to address many current global social and environmental issues than neo-conservative branches of Christianity would care to admit?

Difficult as this may be to accept for many in as highly religious a society as South Africa, this country elicits the same kind of question, however, by its example in the opposite: how could such a generally conservativelyChristian society (more than $80 \%$, and rising) manifest such extreme levels of crime, violence, corruption, poverty and social neglect? How can a realist view of God be reconciled with such ethically speaking directly unchristian behaviours?

\section{Conclusion: Don Cupitt for the 2020s?}

Despite his radicality and controversiality, Cupitt belongs to the hall of fame of contemporary religious thought, finding a welcoming reception beyond the confines of progressive Christianity, for example, within secular Buddhism (Batchelor 2015) and Reconstructionist Judaism. The founder of the latter, Rabbi Mordechai Kaplan, has namely in parallel to Cupitt embraced an 'atheous religiosity' of his own brand, leaning towards the naturalism of John Dewey (cf. SherbookCohen 1985).

The objective of this article has been to draw attention to the relevance of the death-of-God theology, not as the last gasp of liberal Protestant theology, but as something still worthy of attention, especially with the framework of Cupitt's argumentation drawing on the best traditions of criticism of religion of the past two centuries. The idea of objective theism may not be as firmly re-established after its quavering in the wake of the Enlightenment and post-Enlightenment criticism, as some may still be swayed to believe today. However, we should not wave away that segment of spiritually oriented people for whom God is conceivable only as an 'impossible love' similar to their deceased parents or a meaning-giving 'leading idea' in their lives. If mainstream Protestantism is withering away, is conservative evangelical Christianity the one we wish to see succeeding it, with its promotion of the image of God as a highly anthropomorphised and sentimentalised figure healing our uncertainties in this life and offering an eternal abode in the future one?
Cupitt is by no means alone in articulating the goals of a religion purged of Plato's otherworldly layer. In his latest book, Hoping against the Hope, Caputo confesses that contrary to what he had been taught by his religious teachers and superiors about eternity having a metaphysical meaning, now having reached advanced age, he is certain that to 'eternity' can be imparted only a poetic meaning. Traditional Christianity has been harnessed too much by the 'economy of salvation', which has a proclivity to treat life only in judiciary or stockbroking terms as a span of time lived merely in the expectation of eternal reward or damnation. As Caputo adds, this is religion at its worst, himself opting for faith understood as a gift that blossoms because it simply blossoms: 'Life is life/death, living on, outliving death for a time, and the economy of salvation is life's worst enemy' (Caputo 2016:39).

There are, however, aspects of Cupitt's thought that remain in the category of utopia, above all his overtly postmodern optimistic valuation in the 1990s of the process of globalisation. In his 1997 After God: The Future of Religion, Cupitt cautiously probed the vision of a new globalised world religion that would not divide humanity into 'us' and 'them', but which would rather give a voice to the collective consciousness of the whole human race (Cupitt 1997:122). This vision seems to have turned out to be misconceived, given developments that have been taking place in many parts of the world during this decade which favour an angry tribalism or localism, which does not care for anyone outside of an own fold and which has brushed aside the most prominent virtue of post-modernism: humility - in particular, epistemological humility.

A significant twist in epistemology could be seen in the making already in the 2000s, in for instance the return to realism in the philosophy of John Searle (Vatimo \& Zabala 2011:26-36). Can one assume that this is a 'tribalist' tendency, labelled by some as 'post-postmodernism' (Roberts 2016)? Will it surge in the years to come?

If it turns into a negative development, such a postpostmodernism will not be one chastened by difference and otherness, as post-modernism had been: it would not care about it or would be angered by it. The latter would be in vain: in spite of being challenged by 'tribalist' discourses, globalism as such will not be eradicated, because current capitalism thrives on it. Cupitt has been awoken to this dramatic shift and took a stance against it in his 2016 book with its slightly pessimistic overtones in the title: Ethics in the Last Days of Humanity. In it, he addressed the predicaments of our civilisation, from overpopulation, through global warming and widening social inequality, to massive migrations, all of which could potentially lead to the collapse of our civilisation. However, Cupitt sees a partial remedy to these burning problems in (post-)Christian radical humanism and humanitarianism (Cupitt 2016:11-31). Our situation has probably become eschatological, in the sense that the death of God may have triggered the death of creation and hence also the death of humanity. There is nobody out there to love us, so we as humans fall back on each other and must love 
each other, embracing each other in radical humanism. (Post-)Christian humanism and humanitarianism seem to be the ethics for the 'eschaton'. Cupitt sets this against the current anti-humanism of Muslim extremism, rooted in its objective theism, manifested in the cruelties of an Islamic State intentionally set up to reach the widest possible audience through social media. To be a (post-)Christian radical humanist and humanitarian means for Cupitt admiring such people as the British medical aid worker William Pooley, who selflessly got involved in battling the outbreak of Ebola in Sierra Leone in 2014, while contracting the disease himself in the process (Cupitt 2016:21).

Sympathetic as one may be to Cupitt's vision of the diffusion of the message of the Gospels into radical (post-)Christian humanitarianism, nevertheless, we cannot be certain whether it is wise to put all the eggs of the Christian heritage into one basket. The recent large-scale sex abuse scandals which rocked humanitarian agencies (which parallel in some respects those in the ecclesial world) seem to have compromised the very calling of the humanitarian mission in the so-called Third World, uncovering something ominously unhealthy about the moral integrity of the societies of the First World. Irrespective of such broader-scale problems, Cupitt's religious thoughts on (post-)Christian humanitarianism remain a standing legacy for the coming decade.

\section{Acknowledgements Competing interests}

The authors declare that they have no financial or personal relationships that may have inappropriately influenced them in writing this article.

\section{Authors' contributions}

D.B. contributed $70 \%$ and C.L. $30 \%$ to the research and writing of this article.

\section{References}

Almond, I., 2000, 'How not to deconstruct a Dominican: Derrida on God and "hypertruth"', Journal of the American Academy of Religion 68(2), 329-344. https://doi.org/10.1093/jaarel/68.2.329

Altizer, T.J.J., 2006, Living the death of God: A theological memoir, New York State University Press, Albany, NY

Arneth, M., 2000, "Sonne der Gerechtigkeit": Studien zur Solarisierung der JahweReligion im Lichte von Psalm 72, Harrassowitz, Wiesbaden, (BZAR 1).

Bailey, E., 1997, Implicit religion in contemporary society, Kok Pharos, Kampen.

Batchelor, S., 2015, After Buddhism: Rethinking the dharma for a secular age, Yale University Press, New Haven, CT.

Berger, P.L., 2011, Adventures of an accidental sociologist, Prometheus Books, Amherst, NY.

Biernot, D. \& Lombaard, C., 2017, 'Religious experience in the current theological discussion and in the church pew', HTS Teologiese Studies/Theological Studies 73(3), 1-12. https://doi.org/10.4102/hts.v73i3.4347

Bourdieu, P., 1986, 'The forms of capital', in J.E. Richardson (ed.), Handbook of theory and research for the sociology of education, pp. 241-258, Greenwood Press, New York.

Brenneman, T.M., 2014, Homespun Gospel: The triumph of sentimentality in contemporary American evangelicalism, Oxford University Press, Oxford.

Caputo, J., 1997, The prayers and tears of Jacques Derrida: Religion without religion, Indiana University Press, Bloomington, IN

Caputo, J., 2016, Hoping against hope: Confessions of a postmodern pilgrim, Fortress Press, Minneapolis, MN.
Cathey, R.A., 2009, God in postliberal perspective: Between realism and non-realism, Ashgate, Hampshire.

Cilliers, J., 1996, Die uitwissing van God op die kansel: Ontstellende bevindinge oor Suid-Afrikaanse prediking, Lux Verbi, Kaapstad.

Cipriani, R., 2017, Diffused religion: Beyond secularization, Palgrave McMillan, London.

Collier, A., 1994, Critical Realism: Introduction to Roy Bhaskar's philosophy, Verso, London.

Cox, H., 2013, The secular city: Secularization and urbanization in theological perspective, Princeton University Press, Princeton, NJ.

Crossan, J.D., 1993, The historical Jesus: The life of a Mediterranean Jewish peasant HarperCollins, New York.

Cupitt, D., 1980, Taking leave of God, SCM Press, London.

Cupitt, D., 1995, The last philosophy, SCM Press, London.

Cupitt, D., 1997, After God. The future of religion, Phoenix, London.

Cupitt, D., 1998, The religion of being, SCM Press, London.

Cupitt, D., 2000, Kingdome come in everyday speech, SCM Press, London.

Cupitt, D., 2001a, Emptiness and brightness, Polebridge Press, Salem, OR.

Cupitt, D., 2001b, Nach Gott: Die Zukunft der Religione, Klett-Kotta Verlag, Stuttgart.

Cupitt, D., 2007, Impossible loves, Polebridge Press, Santa Rosa, CA.

Cupitt, D., 2011, Turns of phrase: Radical theology from A to Z, SCM Press, London.

Cupitt, D., 2012, The Last Testament, SCM Press, London.

Cupitt, D., 2015, Creative faith: Religion as a way of worldmaking, Polebridge Press, Salem, OR, (Kindle edition).

Cupitt, D., 2016, Ethics in the last days of humanity, Polebridge Press, Salem, OR.

Derrida, J., 1976, Of grammatology, Johns Hopkins University Press, Baltimore, MD.

Derrida, J., 1993, 'Circumfession', in G. Bennington \& J. Derrida (eds.), Jacques Derrida, pp. 3-315, University of Chicago Press, Chicago, IL.

De Villiers, P., 2006, 'Spirituality, theology and the critical mind', Acta Theologica, suppl. ser. 8, 99-121.

Geering, L., 2014, Reimagining God: The faith journey of a modern heretic, Polebridge, Salem, OR.

Habermas, J., 2008, 'Secularism's crisis of faith: Notes on post-secular society', New Perspectives Quarterly 25, 17-29. https://doi.org/10.1111/j.1540-5842.2008. 01017.x

Hebblethwaite, B., 1988, The ocean of truth: A defence of objective theism, Cambridge University Press, New York.

Hendrikse, K., 2007, Believing in a God that does not exist: The manifesto of an atheist pastor, Nieuw Amsterdam, Amsterdam.

Hendrikse, K., 2011, God does not exist and Jesus is his son, Nieuw Amsterdam, Amsterdam.

Johnson, G., 2006, 'A free-for-all on science and religion', New York Times, November 212006.

Jüngel, E., 1983, God as the mystery of the world. On the foundation of the theology of the crucified one in the dispute between theism and atheism, Eerdmans, Grand the crucified
Rapids, MI.

Krüger, K., 2006, Sounding unsound: Orientation into mysticism, Aurora Press, Pretoria.

Leaves, N., 2004, Odyssey on the sea of faith: The life \& writings of Don Cupitt, Polebridge Press, Santa Rosa, CA.

Leaves, N., 2005, Surfing on the sea of faith: The ethics and religion of Don Cupitt, Polebridge Press, Santa Rosa, CA.

Leaves, N., 2011, Religion under attack: Getting theology right, Polebridge, Salem, OR, (Kindle edition).

Lombaard, C., 2016, 'God's absence as characteristic of faith: Implicit religion and Edward Bailey (1935-2015), Stellenbosch Journal of Theology 2(2), 257-272.

Lombaard, C., Benson, I.T. \& Otto, E., 2018, 'Faith, society and the post-secular: Private and public religion in law and theology', HTS Teologiese Studies / Theologica Studies 2018. Forthcoming

Lopez, J. \& Potter, G., 2005, After postmodernism: An introduction to critical realism The Athlone Press, London.

Lucado, M., 1996, In the grip of grace, Thomas Nelson, Nashville, TN.

McCloud, S., 2015, American possessions: Fighting demons in the contemporary United States, Oxford University Press, Oxford.

McClure, J.A., 2007, Partial faiths: Postsecular fiction in the age of Pynchon and Morrison, The University of Georgia Press, Athens, GA.

McCullough, L. \& Schroeder, B., 2004, Thinking through the death of God: A critical companion to Thomas J.J. Altizer, University of New York Press, Albany, NY.

Michener, R.T., 2007, Engaging deconstructive theology, Ashgate, Farnham.

Mitchell, S., 1997, Agenda for faith, The Sea of Faith Network, Loughborough.

O'Sullivan, M. \& Flanagan, B. (eds.), 2012, Spiritual capital: Spirituality in practice in Christian perspective, Ashgate, Farnham.

Piggot, R., 2013, 'Doing church without God', BBC News, November 1, 2013. 
Rahner, K., 1965-1991, Theological Investigations (22 Volumes), Darton, Longman \& Todd, London.

Roberts, K., 2016, We are witnessing the end of postmodernism and the beginning of post-postmodernism, Unsystematic Theology with Kyle Roberts, Patheos.

Rorty, R., 1989, Contingency, irony, and solidarity, Cambridge University Press, New York.

Rorty, R., 1998, Truth and progress (Philosophical Papers III), Cambridge University Press, New York.

Sau, N.W.C., 2001, 'Karl Rahner's concept of the "Anonymous Christian". An inclusivist view of religions', Church \& Society 4(1), 23-39.

Schreiber, D., 2012, 'On the epistemology of postmodern spirituality', Verbum et Ecclesia 33(1), 1-8. https://doi.org/10.4102/ve.v33i1.398

Schreiber, D., 2017, 'Lombaard's categorical invitation for minority dissent against "suspicion": How real is the "religious" in post-secular context?', Verbum et Ecclesia 38(1), 1-9. https://doi.org/10.4102/ve.v38i1.1722

Schreiber, D.A., 2013, 'Joined-up knowledge for a joined-up world: Critical realism, philosophy of meta-reality and the emancipation in/of anthropological Spirituality. An exploration of confluences', MTh dissertation, Depart of Christian Spirituality, University of South Africa.

Schüssler, F.E., 1994, Jesus: Miriam's child, Sophia's prophet. Critical issues in feminist Christology, Continuum New York.
Seeskin, K., 2000, Searching for a distant God: The legacy of Maimonides, Oxford University Press, Oxford.

Shakespeare, S., 2004, 'A hiding to nothing: Cupitt and Derrida on the mystery tour', in G. Hyman (ed.), New directions in philosophical theology: Essays in honour of Don Cupitt, pp. 1010-1116, Ashgate Publishing, Aldershot.

Sherbook-Cohn, D., 1985, 'Don Cupitt and reconstructionist Judaism', Theology 88(726), 436-440. https://doi.org/10.1177/0040571X8508800604

Trakakis, N., 2007, The God beyond belief. In defence of William Rowe's evidential argument from evil, Monash University, Melbourne.

Vatimo, G. \& Zavala, S., 2011, Hermeneutic Communism. From Heidegger to Marx, Columbia University Press, New York.

Vogel, J., 2014, 'Can one believe in God that does not exist?', Theologická Revue 85(4), 473-488, (Original Czech).

Vosper, G., 2012, With or without God: Why the way we live is more important than what we believe, Harper Perennial, New York.

Walshe, M. O'C., 2009, The complete mystical works of Meister Eckhart, The Crossroad Publishing Company, New York.

Wolff, M., 2018, Fire and fury: Inside the Trump White House, Little, Brown Book Group, London.

Zuckerman, P., 2008, Society without God: What the least religious nations can tell us about contentment, New York University Press, New York. 